\title{
İklim, Coğrafi Konum, Yer Şekilleri Ve Denizlerin Siyasi Coğrafya Üzerindeki Etkileri
}

\author{
Mustafa KARNIBÜYÜKK ${ }^{1}$
}

\begin{abstract}
Özet
Siyasetin temel faktörleri, insan ve toplumdur. Diğer insanlar, diğer toplumlar ve fiziki çevre siyasetin temel faktörlerini etkilerler. Fiziki çevrenin en somut ve kapsayıcı karşıllığı coğrafyadır. Coğrafyanın unsurların yeryüzüne homojen dağılmamış olması, tarih boyunca bireyleri ve toplumları etkilemiştir. Eski dönemlerde coğrafya, engel olarak görülmüsştür. Ancak tekniğin ilerlemesiyle insanlar, coğrafyanın neden olduğu olumsuzluklardan kaçınmışlar, coğrafyanın sağladığı olanaklardan faydalanmayı bilmişlerdir. Coğrafyanın toplum ve siyaset üzerindeki belirleyici etkisi, teknolojik ilerlemeyle kırılmış gibi görünmektedir. Ancak coğrafya, siyaset ve toplumu etkileyerek siyasal süreçler üzerindeki etkilerini sürdürmektedir. Aynı zamanda coğrafyanın siyaset üzerindeki etkileri dolaylı olarak, tutum ve davranışları şekillendiren kültür üzerinden de net bir şekilde görülmektedir. Bu nedenle siyaset - coğrafya ilişkisini, jeopolitik ve siyasi coğrafya bilimlerinde olduğu gibi güç kavramı etrafında incelemek yeterli olmamaktadır. İngiltere, siyasete dair Kıta Avrupası'ndan farklı tutum, davranış ve kurumlara sahiptir. Avrupa ve Asya'nın siyasi düşünce tarihine çok farklı katkıları olmuştur. Siyaset biliminin tartışma alanları etrafında coğrafya - siyaset ilişkisine, farklı bir bakış açısı getirilebilmektedir. Makalede, başlıkta verilen coğrafi unsurların siyasete dair etkileri, tarihten örnekler ve konu hakkında çalışmış düşünürlerin görüşleriyle ele alınmıştır. Makale sonucunda, coğrafya - siyaset arasındaki ilişkiyi, determinist ve güç odaklı bir bakış açısı ile sınırlamadan dikkate almanın, hem siyasete hem ilişkiye dair daha fazla fikre ışık tutabileceği sonucuna varılmıştır.
\end{abstract}

Anahtar Kelimeler: Siyaset, Coğrafya, Coğrafi Unsurlar, Birey, Toplum.

\section{The Effects Of Climate, Geographical Location Landforms And Seas On Political Geography}

\begin{abstract}
The main factors of politics are people and society. Other people, other societies and the physical environment affect the main factors of politics. The most concrete and inclusive equivalent of the physical environment is geography. The fact that the elements of geography are not distributed homogeneously on earth has influenced individuals and societies throughout history. In ancient times, geography was seen as an obstacle. However, with the advancement of the technique, people have avoided the negativity caused by geography and they have been able to benefit from the opportunities provided by the geography. The decisive influence of geography on society and politics seems to be broken by technological progress. However, it affects the political processes by affecting geography, politics and society. At the same time, the effects of geography on politics are indirectly seen through the culture that shapes attitudes and behaviors. Therefore, it is not enough to examine the relation between politics and geography around the concept of power as in the geopolitical and political geography sciences. England has different attitudes, behaviors and institutions about politics than Continental Europe. Europe and Asia have made very different contributions to the history of political thought. A different point of view can be brought to the relationship between geography and politics around the areas of political science. In this article, the effects of the geographic elements given in the title of politics, the examples from the history and the thinkers who have worked on the subject are discussed. As a result of the article, it was concluded that considering the relationship between geography and politics without limiting it from a determinist and power-oriented perspective could shed more light on both politics and connection.
\end{abstract}

Keywords: Politics, Geography, Geographical Elements, Individual, Society.

${ }^{1}$ Tezli yüksek lisans öğrencisi, Bursa Uludağ Üniversitesi, Sosyal Bilimler Enstitüsü, Siyaset Bilimi ve Kamu Yönetimi Anabilim Dalı, Siyaset ve Sosyal Bilimler Bilim Dalı, karnibuyukm@gmail.com 


\section{Giriş}

Siyaset, topluluk halinde yaşayan insanlar arasında doğmuştur ve doğası gereği insan odaklıdır (Kışlalı 2004: 21). Dolayısıyla siyasetin temel aktörleri insan ve toplumdur. Ancak bu aktörler hem diğer beşerî faktörlerle hem de fiziki faktörlerle etkileşim halindedir. İnsan ve toplumu etkileşim halinde olan bu fiziki faktörlerin en somut ifadesi, insan ve toplumların mutlak bir şekilde bir yer kapladığı, yaşadığı fiziki çevredir. Fiziki çevrenin de en genel ifadesi olan, bu alanı inceleyen bilimin adı olan coğrafyadır. Fiziki çevre de değişken ve dinamiktir. Fiziki çevreye bu özelliği sağlayan insan ve doğadır. İnsan tarım gibi ekonomik, yerleşim gibi sosyal, kültürel vb. süreçlerle beşerî faaliyetler sonucunda bunu sağlarken, doğa; meteorolojik, morfolojik, hidrolojik, vb. coğrafi süreçlerle yeryüzünü şekillendirerek fiziki çevreyi meydana getirmektedir (Eğribel 2006: 212). Coğrafyanın, insan ve doğa üzerinde etkileri vardır. Dolayısıyla coğrafyanın etkilerinin, siyasete ilişkin sonuçları olmuştur.

Coğrafi unsurlar, siyasal olarak edilgen değildir, siyasetle karşıllklı bir etkileşim söz konusudur, güçlendirme ve zayıflatma özelliği vardır. Bu unsurlar yeryüzünün her yerinde eşit olarak bulunmadıkları, kolay elde edilemedikleri, insan yaşamı için gereksinim duyulan ve tükenebilir oldukları için eşit olmayan güç ilişkilerinin bir aracı halini almıştır. Bu nedenle coğrafi unsurların siyasal etkileri olur, siyaset üretir ve siyasete konu olurlar. İnsanların topluluklar halinde yaşaması, güç ilişkilerinin yani siyasetin doğmasını da beraberinde getirmiştir (Hacısalihoğlu 2008: 27). Coğrafya, siyasal ortamı doğurmakla kalmaz, unsurlarıyla, süreç içerisinde yaşadığı değişimlerle, insanlara sunduğu olanaklarla siyasal yaşamı şekillendirmeye, yönlendirmeye devam eder. Tekniğin gelişmesiyle insanlık coğrafyaya üstünlük kurma çabası içerisine girmiştir. Ancak günümüzde dahi bu üstünlüğü tam anlamıyla sağlayamamıştır. Coğrafi faktörler, siyasal yaşamı şekillendiren en istikrarlı faktörlerdendir (Morgenthau 1970: 141).

Coğrafi faktörlerin neden olduğu farkl1lıkların; toplumların yaşayış, beşerî ilişkileri, siyasal tutum ve davranışları gibi siyaseti ilgilendiren pek çok konuda etkili olduğu belirtilmektedir (Arı 1999: 219). Örneğin; deniz kıyısında yaşayanlar ve iç kesimlerde yaşayanlar, verimli arazilerde yaşayanlar ve çöllerde yaşayan insanlar eşit şartlarda değildir. Bu gibi durumlar farklı yaşayış biçimlerinin, farklı toplumsal yapıların ortaya çıkmasına ve dolayısıyla siyasete dair farklılıklara neden olmuştur. $\mathrm{Bu}$ durum, Antik Yunanlılardan başlayarak birçok düşünürün üzerinde çalışma yaptığ1, fikir geliştirdiği bir konu haline gelmiştir (Sorokin 1994: 102). Tarihsel süreçte Aristoteles, İbni Haldun ve Montesquieu tarafından siyasete ilişkin birçok sorun coğrafi faktörler üzerinden sistematik bir şekilde ele alınmıştır (Kışlalı 1987: 28). Ancak bu görüşler, kanıtlanabilirliği ve istisnai durumları nedeniyle tekniğin gelişmesiyle önemini yitirip göz ardı edilmiştir. Coğrafi keşifler ile birlikte ise siyaset ve coğrafya arasındaki ilişki, salt güç odaklı bir ilişki olarak ele alınmış (Günel 2006: 192), jeopolitik ve siyasi coğrafya bilimlerinin konusu haline gelmiştir. Salt güç odaklı bir 
yaklaşım ilişkiye dair dar bir bakış açısı sunmaktadır. Yani, siyasi coğrafya, siyaset ve coğrafya arasındaki ilişkiyi genel bir şekilde ele alırken; jeopolitik, dış politikanın belirlenmesinde coğrafyanın oynadığı rol üzerinde durmaktadır (Demir 1998: 293).

Tarihsel süreç içerisinde ortaya konan görüşler; devlet kavramına bakış, özgürlük eğilimleri ve bireyselci-toplulukçu eğilimler gibi siyasetin önemli sorunsallarına cevaplar getirmiştir. Yakın dönemde Huntington ve Harari de bu konuda çalışmalarda bulunmuştur. Çalışmada, farklı bölgelerde siyasete dair tutum ve davranışlara değinerek dört coğrafi faktör ele alınmış, siyasi coğrafya ve jeopolitik bakış açısı dışında siyasetin temel konu ve sorunsallarına yönelik ortaya konan görüşlere yer verilmiştir. Çalışma, siyasete ilişkin tutum ve davranışlardaki farklılıkların coğrafi sebeplerinin ne olduğu ve bunların doğrudan veya dolaylı olarak nasıl yansıdığı sorusuna yönelik düşüncelerin ortaya konduğu dönemin şartları, determinizm eleştirileri ve ölçekleri dikkate alınarak günümüze kadar gelen süreçte sunduğu, siyaset düşüncesine dair farklı bakış açılarına 1şık tutmayı amaçlamaktadır.

\section{Coğrafya-Siyaset İlişkisi}

Toplumsal yapıya bağlı olarak siyaset farklılık arz etmektedir. Siyasetin özelliklerine nüfuz etmek isteniyorsa, önce toplum yapısının özelliklerine nüfuz etmek gerekmektedir (Oktay 2003: 83). Topluluk ile toplumsal ve politik çağrışımları nedeniyle, coğrafya arasında sürekli bir etkileşim söz konusudur. Teknolojik düzey bile bir anlamda bu etkileşimin ürünü olarak kabul edilmiştir. Teknolojik düzey ve coğrafyanın sağladığı imkânlar ekonomik yapıyı, ekonomik yapı ise siyasal gelişimi etkilemektedir. Coğrafya aynı zamanda, siyasal yaşamın gelişimini ve dönüşümünü yönlendiren nedenleri içerisinde barındırmaktadır (Kışlalı 2004: 21).

Coğrafya, coğrafi unsurların çeşitliliği ve etkisi nedeniyle tarihin başlangıcından en azından teknolojinin geliştiği dönemlere kadar beşerî hayat ve faaliyetler üzerinde oldukça belirleyici olmuştur (Morgenthau 1970: 141). Ancak teknoloji ile kastedilen ulaşım, haberleşme ve savaş teknolojilerinin gelişmesi yüzünden coğrafyanın etkilerinin hiç kalmadığını söylemek de yanıltıcı olur. Siyaset bilimi literatürü açısından birçok önemli ismin de katkıda bulunduğu çalışmalarda insanların karakterlerinden davranış biçimlerine, toplumsal ilişkilerinden, inşa ettiği kurum ve kurallara kadar birçok önemli unsur insanların içerisinde yaşadığı coğrafya ile yakından ilişkilendirilmiştir. Bugün eskisi kadar belirleyici etkisi kalmadığı kabul edilmekle birlikte coğrafi koşullar, insan ve toplumlar üzerinde farklı şekil ve boyutlarda etkili olurlar ve geçmişteki etkilerini doğrudan olduğu gibi dolaylı yollardan da kültür, gelenek ve görenekler aracılığıyla günümüzde bir şekilde yansıtmaktadırlar.

Tarihsel süreçte düşünürler, siyasete dair pek çok gelişmeyi coğrafi faktörleri esas alarak ele almıştır (Sorokin 1994: 102). Bu yönlü yaklaşımlara tarihin eski dönemlerindeki gelişmelere ilişkin değerlendirmelerde daha sık rastlanmaktadır. İnsanlık tarihinin başlamasıyla birlikte insanoğlu yaşamını sürdürebilmek için uygun yerler aramış, bu arayışların sonunda da Akdeniz ve Mezopotamya çevresinde yerleşimler kurmuştur. Paleotik Çağ adı verilen bu devrin başlarında iklim aşırı derecede 
sıcak olduğu için insanlar akarsu ve göl kenarlarına yerleşmeyi tercih etmiştir. Zamanla iklimin yumuşaması, insanoğlunun ateşi buluşu, hayvanları ehlileştirmesi ve hayvancılığı öğrenmesiyle insanlığın toplu yaşaması, köy yaşantısı başlamıştır (Kıvılcımlı 1974: 2). Bu durum insanın doğasını ortaya çıkarmış, birlikte yaşamanın bir sonucu olarak sosyal olaylar meydana gelmiştir (Dönmezer 1984: 1).

Fırat-Dicle havzasına yerleşen Sümerlerde yeryüzündeki her şeyin Tanrı'nın malı olduğuna inanılmıştı. Söz konusu inanışa göre Tanrı'nın olduğu kabul edilen ancak yaşamsal anlamda genel itibariyle elverişsiz durumdaki bu toprakları verimli hale getirmek, bunun için de bataklıkları kurutmak ve sulama kanalları inşa etmek gerekiyordu. Bütün bu zor işleri başarmak ise ancak ortak bir emeğin ortaya konması ile mümkündü. Böylece halk birlikte kanallar açıyor, toprağı birlikte işliyor ve yetişen ürünleri birlikte topluyorlard. Toplanan ürünler ise "ziggurat" denen mabede getiriliyordu. Mabette toplanan ürünler daha sonra her ailenin ihtiyacı oranında paylaştırılıyordu. İhtiyaç fazlası ürünler ise satılıyor elde edilen gelirle yerine ihtiyaç duyulan diğer ürünler alınıyordu. Yaklaşıma göre Mezopotamya'nın coğrafi şartları neticesinde, Sümer şehir devletlerinde "emekte ve nimette ortaklık" esasına dayanan yeni bir idare şekli, yeni bir rejim doğmuştu. Batılı tarihçiler bu durumu bir çeşit ilkel sosyalizm olarak da nitelendirmektedir. Fakat bu sosyalizm gücünü Tanrı'dan aldığı için ona "mabet sosyalizmi" ya da "teokratik sosyalizm" de denilmektedir (Memiş 1990: 22).

Yukarıdaki örnek gerek jeopolitiğin gerek siyasi coğrafyanın ötesinde bir coğrafya-siyaset ilişkisine işaret etmektedir. Coğrafi şartlar örnekte, güç ilişkisinin ötesinde örgütlenmeye dair bir sosyal gelişmeye neden olmuştur. Elbette benzer coğrafi şartlar siyasete dair benzer gelişmeleri doğurmamaktadır. Farklı toplumsal birikimler, coğrafi koşulların farklı şekillerde yorumlandığı, faydalanıldığı, bunun da farklı gelişmeleri meydana getirdiği durumlar söz konusudur. Eski Mısır, Fırat-Dicle havzasıyla benzer coğrafi koşullardaki Nil nehri etrafında kurulmuş olmasına karşın diğer coğrafi faktörler ve farklı toplumsal şekilleniş nedeniyle farklı bir yapıya sahipti. Başka bir coğrafi faktör olan çöl, siyasete dair sonuçları itibariyle nehirden, pek çok alanda baskın gelmiştir. Kaynakların kıtlığı, güç ilişkilerinin belirginleşmesi burada farklı bir devlet yapısını beraberinde getirmiştir. Diğer taraftan coğrafi faktörün kendisine değil neden olduğu koşullara bakıldığında farklı coğrafi faktörler de siyasete dair benzer sonuçlar doğurabilmektedir. Norveç’te fiyortlar, İsviçre'de dağlar birbirinden kopuk farklı toplumsal ve siyasi yapıların ortaya çıkmasına neden olmuştur (Özcan 2006: 337). Coğrafi koşulların etkileri toplumsal boyutta daha belirgindir. Coğrafi koşullar toplumların yaşayış biçimini, kuralları ve kurumlarını etkilemektedir. Antik Yunanlıların agorası, Romalıların forumu, Berberilerin cemaaları eski çağ demokrasilerinin açık hava koşullarına bağlı olduklarının göstergesidir (Duverger 1984: 49).

Coğrafya bir şekilde toplumsal yapıyı etkilemiş, bu siyasete de yansımış ve farklı devlet yaklaşımları ve farklı yönetim biçimlerinin ortaya çıkmasında coğrafi unsurlar dolaylı olarak etkili olmuştur. İlk çağlardan itibaren, coğrafi bilgi; kendisinin farkında olup onu, yapmış olduğu tüm 
faaliyetlerde en üst düzeyde hesaba katan toplumlara çeşitli avantajlar sağlamıştır ve halen sağlamaya devam etmektedir (Demirci 2011: 3). Bu tanım, hem uluslararası arenadaki güç ilişkilerini hem de toprak parçasına bağlı bir siyaset analizini de kapsamaktadır. Ancak yukarıda verilen örnekler coğrafya-siyaset ilişkine, jeopolitik ve siyasi coğrafya penceresinden bakmanın yeterli olmayacağının ve siyaset biliminin sorunsallarıyla bu ilişkiye farklı bir bakış açısı getirebileceğinin göstergesidir.

\section{Coğrafi Unsurlar ve Siyasete Olan Etkileri}

Tarihte, düşünürler tarafından coğrafi unsurlar ile pek çok konunun ilişkilendirildiği kuramlar ortaya atılmıştır. Bu kuramlar içerisinde öne çıkanlar arasında coğrafya ile siyaseti ilişkilendiren kuramlar da vardır (Kösemihal 1982: 50). Siyaset ve coğrafi faktörler arasında ilişki kurma çabası çok eskiye dayanan bir geçmişe sahiptir ve farklı isimler tarafından farklı biçimlerde ele alınmıştır (Sönmezoğlu 1989: 397). Coğrafi koşullar bireyin kişiliğini ve eğilimlerini şekillendiren önemli bir faktördür. Bu koşullar bireyin yapısı, dünyası ve özgürlügüÿle yakından ilişkilidir. Bu bağlamda; toplumun siyasi organizasyon biçimi, barışçı ya da askeri karakteri, toplumun iyimserliği ya da kötümserliği, özgürlük aşk1 ya da tabi olma isteği (Sorokin 1994: 146) gibi pek çok siyasete dair eğilim coğrafi etki çerçevesinde değerlendirilmiştir. Bununla birlikte insanların siyasi bir organizasyon meydana getirme yeteneği bazı bölgelerde daha fazla gelişmiş ve yerleşmiş ise bunun nedenlerini insan faktöründe aramak kadar çevre şartlarında da aramak gerekmektedir (Göney 1979: 127).

Burada coğrafi unsurlarla kastedilmek istenilen şeyi tanımlamak gerekmektedir. Coğrafi unsurlar; varlığı insan eylemlerinden bağımsız, insan müdahalesi olmadan da değişebilen veya çeşitlenebilen, doğanın insanlara sağladığı çevreyi oluşturan öğelerdir (Sorokin 1994: 102). İklim, dağlar, hayvanlar, bitkiler, okyanuslar, depremler, rüzgârlar coğrafi unsurlar olarak kabul edilirken köyler, kanallar, yapay bahçeler antropolojinin konusudur. İnsan coğrafi unsurların bir bölümünü kısmen veya tamamen kontrol edebiliyor olsa da coğrafi unsurların tamamı için böyle bir güce sahip değildir (Dönmezer 1984: 67). Coğrafi unsurlar yeryüzünde homojen bir dağılım göstermediğinden yeryüzünün her kesiminde birey ve toplum üzerinde farklı şekilde etki bırakmaktadır. Wentzel'e göre coğrafyanın ana unsurlarını konum, genişlik, iklim, yer şekilleri, biçim ve doğal kaynaklar oluşturmaktadır (Say 2011: 391). Bu anlamda iklim, sıcaklık, denizellik-karasallık, yer şekilleri, arazi yapısı, arazi verimliliği gibi başlıca coğrafi faktörler; boyutları, şiddetleri, durumları itibariyle birey ve toplumların yaşayış ve ilişki biçimlerinden siyasete dair kararlarına, kurum ve kurallarına kadar toplumsal ve siyasi hayata ilişkin konuya da yön vermektedirler.

Nehir, dağ, deniz gibi coğrafi unsurlar yeryüzünü belli kısımlara ayırmaktadır. Yeryüzünün her bir unsuru, içinde veya yanında yer alan bir parçasına kendi özelliklerini vermekte ve hatta adeta bazı özellikleri damgalamaktadır (Göney 1979: 56). Bu coğrafi unsurlar, orada yaşayan insanları da etkilemektedir. Her coğrafi unsur orada yaşayanlar için farklı bir mücadele şekli anlamına gelmektedir. Bunun etkileri kültürlerine yansır ve bunun sonucunda toplumlar birbirlerinden 
farklılaşır. Pek çok çalışmada; Afrika örneğinde olduğu gibi gelişmişliğe ilişkin kıtalar arasındaki farklılıkları, Akdeniz ülkeleri ile Orta ve Kuzey Avrupa ülkelerinin sosyolojik farkl1lıkları gibi ülkeler arasındaki farklılıkları, ABD'nin doğusu ve batısı arasındaki sanayileşmeye dayalı ülke içesindeki farklılıkları açıklamak için sırasıyla bitki örtüsü, iklim ve yer şekillerine başvurulmuştur. Örneklerin sayısı ve başvurulan coğrafi unsur değişebilmektedir. Ancak ilgili çalışmalar incelendiğinde siyasete dair farklılıkları açıklamada bazı coğrafi unsurlar öne çıkmaktadır. Özellikle iklim, gerek coğrafyaya ilişkin pek çok etki ve unsuru kapsayıcılığı ve insanoğlunun henüz tam anlamıyla hâkim olamaması nedeniyle öne çıkmaktadır.

\section{1. İklim}

Coğrafyanın etkileri söz konusu olduğunda en öne çıkan unsuru iklimdir. Zira iklim, son derece büyük çaplı olan gezegen hareketleri ve uzun yıllar süren hava olayları sonucunda ortaya çıkmış bir etkendir. Bu nedenle iklim kapsayıcı bir ifadedir. Diğer pek çok coğrafi unsurun varlığı, etkinliği iklimle ilişkilidir. Çünkü iklim, diğer coğrafi unsurların etkilerini artırabilecek ve azaltabilecek güce sahiptir. İklimin etkilerini inceleyen düşünürlerin yaklaşımı da bu yönde olmuştur. Coğrafya ile siyaset arasındaki ilişkiyi siyaset bilimi çerçevesinde sistemli bir şekilde ele alan üç isim olarak kabul edilen Aristoteles, İbni Haldun, Montesquieu (Kışlalı 1987: 28) ilgili çalışmalarında iklimi öncelemişler, yer yer diğer coğrafi unsurların etkilerini de kapsayacak şekilde çalışmalarının temel unsuru olarak kullanmışlardır.

Elbette iklimi önceleyenler bu üç isimle sınırlı değildir. Pek çok düşünür tarafından siyasete dair örgütlenmelerde, eğilimlerde iklim ön plana çıkarılmıştır. Çünkü iklimin aşırılığı siyasete dair yaklaşım, tutum ve davranışlar üzerinde oldukça etkilidir. İklim şartlarının aşırı olduğu bölgelerde temel ihtiyaçların giderilmesi zor olduğu için buralarda siyasi ve sosyal meseleler arka planda kalmıştır. Günlük yaşam coğrafi şartlara göre biçimlenmektedir. Aşırı sıcağın olumsuz etkilerinden korunmak isteyen insanlar eğer varsa deniz kıyısına, yoksa yüksek kesimlere yönelmişlerdir. Aşırı soğuktan korunmak isteyen insanlar genellikle karaların iç kesimlerine yerleşmişlerdir. Ilıman iklimlerde ise yerleşim genellikle ovalarda kurulmuştur (Strabon 2000: 110). Bundan dolayı siyasi faaliyetler de büyük yerleşimlerin olduğu bölgelerde yoğunlaşmıştır. Çölleşmiş veya kurak arazilerde ancak suyun yeterli miktarda olup toprağın verimli olduğu yerlerde nüfus yoğunlaşıp siyasi yapı ve organizasyonlar ortaya çıkmıştır. Nitekim toprak verimliliği üzerinde kurulan siyasi yapının gelişiminde önemli rol oynamakta; verimsiz topraklarda devletler, medeniyet sahasında çabuk ve büyük bir gelişim gösterememektedir (Göze 1959: 10). Medeniyetler kaynaklar etrafında gelişmiş ve devletlerin yapı ve rejimleri şekillenmiştir. Örneğin; verimsiz toprakların olduğu ne Orta Asya'da ne de Arap çöllerinde istikrarlı bir siyasi yapı kurulamamıştır.

İklimin etkileri yalnızca siyasete dair faaliyetlerin ortaya çıkışıyla sınırlı kalmaz. Siyasi ve toplumsal yapıların bütüncül ya da parçalı bir görünümde olmasında iklimin çeşitli olması önemli bir 
etkendir. Çünkü iklimin çeşitli olması, yaşam tarzlarının ve toplumsal yapıların çeşitlenmesine olanak sağlamaktadır. Bu çeşitlilik de siyasi alana yansıyarak, siyasete bakışın, beklentinin çeşitlemesine ve farklılıklara dayanan bir yapının oluşmasına zemin hazırlamaktadır. Örneğin; Avrupa'nın batısında iklimin ve diğer coğrafi unsurların çeşitlilik göstermesi, siyasi ve toplumsal farklılaşmaların oluşmasına neden olmuşken, doğuya doğru gidildikçe iklim ve coğrafi unsurların benzemeye başlaması giderek bütüncül ve yeknesak toplumsal ve siyasi yapıların oluşmasına, bunun sonucunda da otoriter rejimlerin ortaya çıkmasına sebep olmuştur. Örneğin; Sovyetler Birliği'nin dağılan parçalarında farklı iklimlerin hâkim olduğu görülürken, Rusya'ya kalan coğrafyada ise büyük oranda benzer iklim koşullarının hâkim olduğu aşikârdır (Göney 1979: 137).

İklimin insan ve toplumlar üzerindeki etkisi şartlara bağlı olarak doğrudan olabileceği gibi dolaylı yollardan da olmaktadır. İklim, ekonomik faaliyetleri belirleyerek bunun üzerinden insan ve toplumları etkilemektedir, farklılaştırmaktadır. Örneğin; şiddetli iklim koşulları nedeniyle, doğanın fazla seçenek sunmadığı kuzeyinde tundra topraklarının güneyinde ise çöllerin olduğu Orta Asya, insanları tarım yerine hayvancılığa yönelmeye zorlamıştır. Bütün halinde, çok büyük sürüleri ile birlikte yaşayan göçebe topluluklar, etrafındaki yüksek dağların arasında sürekli otlak ve su kaynakları aramak zorunda kalmıştır. Bu zorunluluk, göçebeliği benimseyen bu topluluklara geniş topraklara hükmetme yeteneği kazandırmıştır. Bunun sonucunda sınırlı bir hâkimiyet alanıyla yetinmeyen Cengiz Han, Timur, Kubilay gibi fatihlerin yönettiği imparatorluklar ortaya çıkmıştır (Duverger 1982: 100). $\mathrm{Bu}$ imparatorlukların tarihi iklim bakımından elverişli bölgelere yapılan göç ve akınlarla doludur. Coğrafyanın dayattığı bu zorunluluklar, dolaylı yollardan devletler arasında siyasi faaliyetleri etkilemiş ve tarihin akışını belirlemiştir.

İklimin etkisi bir devletin içerisinde de diğer coğrafi unsurların varlığı ve çeşitliliği nedeniyle farklılıklar gösterebilmektedir. Coğrafi unsurların eşit dağılmayışı nedeniyle aynı devlet içerisinde fakat farklı bölgelerde yaşayan insanlar aynı etkilere maruz kalmamaktadır. Bu nedenle ülke içerisindeki toplumsal farkl11ıklar tetiklenir. Bu durum eğer kontrol edilebilirse çeşitli ekonomik faaliyetlerin gelişmesine, çeşitlenmesine, devlet içerisinde bölgeler arasında bir dengenin ve tamamlayıcılığın sağlanmasına dolayısıyla siyasi birliğin kurulmasına yardımcı olur (Göney 1979: 133).

İklim baskın bir coğrafi unsurdur. Ancak diğer coğrafi unsurların varlığıyla etkisi değişiklik gösterebilmektedir. Sıcaklık, yağış miktarı ve bitki örtüsü; toplumların karakteri, davranışı, sosyal süreç ve organizasyonunun belirlemesinde etkin olan coğrafyanın önemli unsurlarındandır (Sorokin 1994: 107). Bu unsurların azlığı ve çokluğu siyasi faaliyetleri olumsuz yönde etkileyebilmektedir. Aşırı yağış genelde sık bir bitki örtüsüne sebep olmuştur. Kıyılarda yaşayanlarla iç kesimde yaşayanlar arasında farklılık ve kopukluk söz konusudur. Bu durum insanların birbiriyle daha az iletişim ve etkileşim halinde olması ve farklı karakterdeki toplumsal yapıların ortaya çıkması ile sonuçlanmıştır. Örneğin, Hindistan'ın bol yağışl1; göl, bataklık ve ormanların da yoğun olduğu bölge açık tenli ve 
kavgacı insanların alanıdır ve nispeten kuru olan İndus ve Ganj vadisinde yaşayan insanlar ile bir mücadele söz konusudur (Braudel 1996: 40). Bu durum Afrika kıtasında da görülmektedir. Yağışların azlığı bitki örtüsünün seyrekleşmesine ve sıcaklık faktörünün ön plana çıkmasına neden olmuştur. Afrika kıtasının kuzeyi Sahra çölü ile kaplıdır. Sıcaklık nedeniyle bölgede ancak sahil şeridinde yerleşim kurmak olanaklıdır. Sahil kısımlarında ise düzensiz yăğşlar sebebiyle tarımsal faaliyetler zorlaşmıştır. Bu nedenle insanlar ihtiyaçlarını karşılamak için başka bölgelere yönelmiştir. Bu durum bölgenin büyük bir bölümünün nüfus bakımından seyrekleşip izole kalmasına sebep olmuş ve siyasi faaliyetler için kısıtlı bir ortam oluşmuştur. Afrika'nın orta kısımlarında ise ekvatoral iklim ve yağmur ormanları sayesinde kısmen çiftçilik yapılabilmektedir. Sıcaklık ve nemin daha makul bir seviyede olması sebebiyle orta kısımda, kıyılar daha yaşanabilir haldedir. Ancak iç kesimlerinde, bitki örtüsünün sıklığı nedeniyle nüfus seyrek ve etkileşim azdır (Roskin 2009: 640). Sıcağın ve nemin yüksek, yağışın bol olduğu bu kuşak, Amazon ve Kongo havzalarını da kapsamaktadır. Buralarda tüm bu coğrafi şartlar nedeniyle nüfus her zaman seyrek olmuş dolayısıyla siyasal düşünce tarihinde buralardan doğmuş kayda değer bir gelişme söz konusu olamamıştır. İklim şartları nedeniyle toplumsal hayat gelişmemiş, siyasi hayat ise ancak kuşak üzerindeki dağlık kısımlarda gelişme şansı bulmuştur (Göney 1979: 131). Bu iklim kuşağında yağışın ve bitki örtüsünün daha seyrek olduğu Habeşistan bölgesi ve And dağları, siyasi hayatın gelişim gösterdiği alanlar olmuştur. Bu kuşağın doğusunda yer alan Hint Okyanusu'nun kıyı ve adalarında ise iklimin aşırı etkileri denizin etkisiyle azalmış, insanlara ekonomik faaliyetler yapma şansı ve canlı bir toplumsal hayat imkânı doğmuştur (İbni Haldun 1982: 334).

Yağışla ilişkin başka bir örnekte; Avrupa genelinde ise yağış hem yeterli miktardadır hem de istikrarlıdır. Bu durum toprağın kıta genelinde birbirlerine yeterli ve yakın verimlilikte olmasına olanak sağlamıştır. Böylece Avrupa'da sulama kanalı, tarım gibi kolektif faaliyetler yapmak zorunlu bir durum olarak görülmemiştir (Özcan 2006: 337). Avrupa'nın coğrafi koşulları böyle bir örgütlenmeyi zorunlu kılmazken, dünyanın pek çok yerinde böyle bir durum söz konusu değildir. Su, özellikle de temiz su, sınırlı bir kaynaktır. Bu durum, dünyanın birçok yerinde kaynakların verimli kullanımı ve kontrolünü zorunlu kılmıştır (Roskin 2009: 508). Farklı kıtalardan örneklerde görüldüğü üzere yağışın, sıcaklığın az veya çok bitki örtüsünün yoğun ya da seyrek olması siyasete dair farklı gelişmelere yol açmışken bu unsurların itidalli olması siyasete dair gerek örgütlenme biçimi gerek düşünce sistemi açısından daha elverişli bir ortam sunmuştur.

Coğrafi unsurlar arasında özellikle iklim, yağış miktarı ve bitki örtüsünün etkileri, yüzyıllar boyunca birey ve toplumlar üzerinde belirleyici bir rol oynamasına rağmen teknolojik gelişmeler sonucunda bu rolü geri planda kalmıştır. Ancak tarihsel süreçte, bu teknolojik gelişmelerin dünyanın her tarafında eşit bir şekilde yaşanmaması, her birey ve toplumun coğrafyanın zorluklarına karşı eşit direnç gösterememesine, bu da ülkeler arasında bugün kapatılması oldukça zor olan bir gelişmişlik farklılığına neden olmuştur. Gelişmiş ve az gelişmiş ülkelerin dağılımı harita üzerinde karmaşık gibi 
görünüyorsa da iklim açısından bakıldığında bu dağılım bir anlam ifade etmektedir. Sosyal ve ekonomik gelişmişliği harita üzerinden incelediğimizde, az gelişmişlik; kutup bölgelerinde, tropikal bölgelerde ve tropik altı çöl bölgelerinde görülmektedir. Gelişmişlik ise, 1lıman iklimin olduğu bölgelerde görülmektedir (Duverger 1984: 51). Elbette bu ve benzeri toplum ve siyasete dair durumlar iklimle tam anlamıla paralellik göstermez. Bu farklılıkların ortaya çıkmasında diğer coğrafi unsurların da etkisi vardır.

\subsection{Coğrafi Konum ve Genişlik}

İklim faktörü gerek beşeri hayat için gerek diğer coğrafi faktörler için son derece güçlü ve kapsayıcı bir etkiye sahiptir. Ancak bu etki harita üzerinde olduğu gibi; paralellerle, meridyenlerle doğrusal bir karakterde değildir. Diğer coğrafi unsurların varlığı ya da konumu, iklimin etkilerini değiştirebilmektedir. Bu sebepledir ki; birey ve toplumun coğrafi konuma bağlı olarak, coğrafi unsurların homojen olarak dağılmadığı yeryüzünde farklı coğrafi unsurlardan farklı derecelerde etkilenmesi söz konusudur. $\mathrm{Bu}$ da gerek sosyolojiye dair gerek siyasete dair farklı tutum ve davranışlara zemin hazırlamaktadır. Değiştirilemeyen karakteriyle coğrafi konum, siyaset üzerinde oldukça etkili bir coğrafi unsurdur. Coğrafi konum sadece üzerinde yaşayanları değil, etrafını da etkilemektedir (Göney 1979: 78). Önemli coğrafi konumlar arasında yer almak, hac, ticaret, istila yolu fark etmeksizin bunların hepsi insanlar veya toplumlar arasında temas kurulmasını, etkileşimi sağlamıştır (Duverger 1984: 54). Antik Yunan medeniyeti tarım açısından verimsiz bir arazide kurulmuş olsa da Doğu-Batı arasındaki konumu ve denizle olan ilişkileri onları önemli hale getirmiştir. Konumun siyasete dair daha doğrusal etkileri de olabilmektedir; yakın çevredeki siyasete dair faaliyetler daha dikkat edilmesi gereken bir hal alabilmektedir. ABD’nin komünizme bakışı, yanı başındaki Küba'da filizlenmesiyle bambaşka bir hal almıştır (Duverger 1984: 55).

Coğrafi konuma diğer coğrafi unsurlardan önce değinmemizin nedeni; tıpkı iklim gibi, diğer coğrafi şartları etkileyebilmesidir. Japonya da tıpkı İngiltere gibi bir ada ülkesidir ancak coğrafi konumu, İngiltere ile benzer bir siyasi geçmişe sahip olmasını engelleyen nedenlerden biri olmuştur. İki ada ülkesinin yanı başındaki kıtalar olan Asya ve Avrupa siyasete dair farklı gelişmelerin ve farklı birikimlerin yaşandığı kıtalardır. Japonya'nın yanı başındaki Asya'nın coğrafi yapısı; arazinin doğal engeller barındırmaması nedeniyle kolay işgal edilip geniş imparatorluklara imkân tanıması, Avrupa'daki gibi siyasi rekabetin değil sürekli baskın bir gücün ortaya çıkması, tarihte Moğol istila girişimi gibi Japonya için birçok tehdit oluşturmuş ve bu nedenle Japonya anakaradan izole kalmayı tercih etmiştir. Çin gibi yakın ülkelerle temas en alt düzeye inmiştir. Bu durum da ayrıca Monarklar ve Feodaller arasında rekabetçi bir yapının oluşmamasını sağlamıştır (Roskin 2009: 416). Ancak ulaşım imkânlarının gelişmesi ile sağlanan Avrupalılarla temas, kaynak yetersizliği yaşamaya başlayan Japonları cesaretlendirmiş ve bundan sonra rekabetçi ve emperyalist bir tutum sergilemesine neden olmuştur. 
Coğrafi konumun siyaset açısından etkilerini daha geniş çapta örneklendirmemiz mümkündür. Bir devletin konumunun kuzey veya güney yarımkürede olması da onun siyasi ve ekonomik ilişkileri ve gelişimi açısından önemlidir. Çünkü bu iki yarımküre coğrafi açıdan önemli farklılıklara sahiptir. Yarımküreler arasından kara ve denizlerin dağılışı yarımkürelerdeki siyasal gelişmelerde etkili olmaktadır. Bunu tetikleyen iklime bağlı coğrafi konumdur. Ilıman iklim kuşağı siyasi ve ekonomik faaliyetlerin ve birikimin en yoğun olarak yaşandığı sahaları kapsaması buradaki devletlerin yeryüzünde siyasi yönden en aktif devletler olmasına sebep olmuştur (Göney 1979: 60). Kuzey Yarımküre'nin 1lıman iklim kuşağının, dünyada karaların en geniş yer kapladığı kuşak olması nedeniyle genel olarak tarih 25. ve 60. derece kuzey enleminde yapılmaktadır (Spykman 2013: 14). Bu nedenle denizlerin önem kazandığı ve mücadele alanları olduğu dönemlere kadar Kuzey ve Güney Yarımküre arasında siyasete dair birikim yönünden makas önemli bir oranda açılmıştır. Elbette Güney Yarımküre'de siyasi faaliyet ve organizasyonlar kuzeyden çok daha sonra da olsa etkinlik kazanmıştır. Ancak, modern kültür ve siyasi fikirler kuzeyden geldiğinden dolayı Güney Yarımküre, kültürel, siyasi ve ekonomik bakımdan Kuzey Yarımküre’ye bağlı kalmıştır (Göney 1979: 58).

Kuzey ve güneye dayalı farklılıklar yalnızca Yarımküreler ölçeğinde değil ülkelerin kendi içerisinde de görülmektedir. Coğrafi konumlarına bağlı olarak ülke içerinde topluma ve siyasete dair farklılıklar meydana gelmiştir. Coğrafi açıdan çok küçük olan ülkeler bir kenara bırakıldığında, Kuzey Yarımküre'deki birçok ülkenin güneyi, kuzeyinden daha az gelişmiş ve halkı da daha yoksuldur. Endüstriyel faaliyetler Fransa, Almanya, İtalya, ABD gibi ülkelerin hep kuzeyinde yoğunlaşmıştır. Söz konusu ülkelerde genellikle kuzeyliler çalışkan ve verimli insanlar olarak nitelendirilirken güneyliler ise eğlenceye düşkün ve tembel insanlar olarak dahi nitelendirilmiştir (Montesquieu 1963: 415). Ekonomik faaliyetleri ve buna bağlı yaşam biçimleri nedeniyle bölgelerin siyasal tutum davranış ve eğilimleri de farklıdır (Kışlalı 1987: 38). Kuzey Kutbu'na yakın olan İskandinav ülkeleri ve Rusya gibi ülkelerde ise tam tersi durum geçerlidir. Gelişmişlik şiddetli soğuğun olduğu kuzey kısımlarında değil, nispeten 1lıman olan güney kısımlarında görülmektedir (Roskin 2009: 154). Coğrafi konuma bağlı olarak mutedil hava şartlarına sahip bölgeler, ülke içerisinde ekonomiye ve siyasete dair faaliyet ve gelişmelerin daha yoğun yaşandığı yerler olmuştur. Görüldüğü üzere coğrafi koşullar gerek küresel anlamda gerek yerel anlamda ekonomik faaliyetlerin farklılaşmasına dolayısıyla siyasete dair talep ve fikirlerin farklılaşmasına sebep olmuştur. Bu nedenle de siyasete dair farklı gelişmeler yaşanmıştır. Aynı ırktan insanlar dahi farklı coğrafi şartlarda farklı eğilim, davranış göstermekte ve farklı gelişmişlik düzeylerine ulaşmaktadırlar. Yine benzer coğrafi koşullardaki farklı ırka mensup kişiler benzer eğilimler göstermektedir. Bu örnekler, aynı zamanda gelişmişlikle ırklar arasında bağlantı kuran kuramlara karşı verilen en iyi yanıtlar olarak gösterilmektedir (Fındıkoğlu 1940: 47).

Yeryüzünde her coğrafi konumda geniş bir coğrafyaya sahip olma imkânı yoktur. Coğrafi açıdan geniş̧lik de siyasete dair son derece önemli sonuçlar doğurabilmektedir. Zira geniş bir coğrafyaya sahip olmak aynı ölçüde farklı coğrafi unsurdan faydalanmayı veya maruz kalmayı 
beraberinde getirmektedir. Tarihte bir devletin siyasi yönden gücü ve önemi genellikle hâkimiyet alanıyla diğer bir ifadeyle genişliğiyle ilişkilendirilmiştir. Genişlik yönünden küçük ülkeler daima istila tehditlerine karşı daha dikkatli olmak zorunda kalmıştır (Duverger 1982: 49). Buna rağmen toprağın durumu, yaşama elverişlilik, iklim şartları, coğrafi konumu, yer şekilleri, ulaşım imkânı gibi coğrafi faktörlerde ve en önemlisi insan faktörü göz ardı edilmemelidir. Japonya ve Rusya örnekleri genişliğin avantaj elde etmekte yeterli bir unsur olmadığının göstergesidir. Ayrıca genişlik siyasete dair her zaman avantaj sağlamamaktadır. Ülke genişliğinin bir diğer etkisi üniter değil, federatif sistemleri zorunlu kılmasıdır. Ulaşım olanakları gelişse dahi, geniş coğrafyalarda merkezin etkisi yine sınırlı kalmakta, bu da merkezci olmayan sistemleri doğurmaktadır (Kışlalı 1987: 34). Buna karşın hâkimiyeti küçük bir sahada olan devletler ise diğer coğrafi faktörlerin imkân verdiği ölçüde bütüncül ve iç işlerinde dinamik bir yapılar kurmuşlar ve çoğunlukla üniter sistemi benimsemişlerdir.

Coğrafi konuma bağlı olarak değişiklik gösterebilen bir diğer unsur da hâkim olunan sahanın şeklidir. Devletin idaresi ve örgütlenmesi açısından bu son derece önemlidir. Bu şekli belirleyen unsurlar arasında elbette coğrafya öne çıkmaktadır. Bu anlamda ülkenin toplu veya dağınık kara parçalarından oluşması egemenliğini ve ülke içi etkinliğini etkileyebilmektedir. Bu bağlamda bir ülkenin şeklinin daireye benzemesi ve başkentinin de bu dairenin tam ortasında bulunmasına siyasi yönden büyük önem atfedenler olmuştur (Göney 1979: 98). Bunun, ülke içinde birliği sağlamada, her noktaya nüfuz etmede, siyasi ve idari hizmetlerin tek bir merkezden ülkenin her tarafina ulaşmasında yardımı olacaktır. Aksi durum hizmetlerin ulaşmasını ve kontrolün sağlanmasını zorlaştırmaktadır. Bu durum, farklı siyasi talep ve eğilimlerin ortaya çıkmasına zemin hazırlayabilir. Ancak buna karşı önlemler almada coğrafya, bazen yer şekilleri ve arazi yapısıyla engel oluşturabilmektedir.

\subsection{Yer Şekilleri ve Arazi Yapısı}

Yer şekilleri, iklimin ve coğrafi konumun yeryüzünü dolayısıyla üzerinde yaşayanları, Ekvator çizgisi ve iklim kuşaklarına bağlı bir şekilde etkilememesinin en önemli coğrafi nedenlerindendir. Yer şekillerinin unsurları, iklimin ve coğrafi konumun etkilerini bazen azaltabilmekte bazen de artırabilmektedir. Dağlar, düzlükler, su kaynakları yeryüzünde dengeli bir dağılım göstermemektedir. $\mathrm{Bu}$ durum elbette beşeri hayat ve faaliyetleri etkilemekte, siyasete dair farklı sonuçların oluşmasına zemin hazırlamaktadır. Örneğin, Asya'da bolca verimli step arazisi vardır. Ancak kuraklık baş gösterdiğinde toprak zarar görür. İnsanlar örgütlü bir şekilde çalışsa da bunun düzeltilmesi mümkün değildir, bu durum zorunlu göçlere yol açmıştır. Zorunlu göçler ve yaşam için elverişli olan sahanın dar olması kamucu bir anlayışın benimsenmesine neden olmuştur. $\mathrm{Bu}$ durum insanları sessiz ve kanaatkâr olmaya itmiştir. Bunun sonucunda da sert bir hiyerarşik, geleneklere dayalı, geniş, ataerkil bir yapı ortaya çıkmıştır (Duverger 1973: 49). Şüphesiz topluma dair böyle bir sonucun ortaya çıkmasını tek bir sebebe bağlamamak doğru değildir. Diğer benzer sahalarla karşılaştırıldığında diğer coğrafi faktörler de dikkate alınmalıdır; dağın yüksekliği ve bölgenin enlem derecesine göre değişen şekilde neresine kadar karla kaplı olduğu, vadilere, dolayısıyla tarıma ve yerleşime ne derece geniş 
imkân sağladığı, ulaşıma ne derece imkân verdiği, iletişim ve etkileşime ne kadar açık olduğu da önemlidir. Arazi yapısı, nüfusun dağılışı ve yoğunluğunu da etkileyerek dolaylı yollardan toplum ve siyaseti etkileyebilmektedir. Siegfried, Batı Fransa'yı inceleyerek dağınık yerleşimin tutucu, toplu yerleşimin ise yenilikçi bir yapıya sebep olduğunu belirtmiştir. Bu durumun sebebini; yalnızlığın içe kapanmaya neden olduğu, kalabalık içinde yaşamanın ise teması sağladığı için yeni düşüncelerin ortaya çıkması olarak açıklamıştır (Duverger 1984: 52).

Dağlar, toplum ve siyasete yönelik etkileri itibariyle yer şekilleri arasında öne çıkmaktadır. Siyaset tarihinde önemli fonksiyonları olmuştur. Dağlar, savunma görevi yaparak bir ülkenin işgal edilmesini zorlaştırabilmektedir. Tarihte Finikelilerin cumhuriyetlerini korumasında etrafindaki dağların katkısı olduğu söylenmektedir. Alpler Almanya'yı güneyden kuşatmayı, Pireneler ise İspanya'yı kuzeyden, Fransa'yı ise güneyden kuşatmayı zorlaştırmıştır. Buna karşın özellikle yaz aylarında, Urallara kadar dağlık arazisi olmayan Rusya'nın batısının savunulması zordur (Roskin 2009: 199). Hint yarımadasının kuzeyindeki yüksek dağlı yapı kuzeyden gelen istila ve farklı kültürel etkilere karşı bölge halkını önemli ölçüde korumuş ve izole etmiştir. Yine Alplerin morfolojik yapısı tarihte o bölgede hâkimiyet kuran Roma İmparatorluğundan İtalya'ya kadar devletlerin, bölgedeki siyasi faaliyetlerinde etkili olmuş, yayılmacı tutum tercih etmeleri durumunda devletleri denize yöneltmiştir. Ayrıca, İsviçre örneğinde olduğu gibi, konumuna rağmen etrafındaki tüm siyasi gelişmelere karşı dağlar, İsviçre'nin siyasi olaylarda tarafsız kalmasını kolaylaştırmıştır (Duverger 1984: 55).

Dağların etkilerini jeopolitik çerçeve ile sınırlamak mümkün değildir. Dağlarda yaşamanın siyaset bilimine dair sonuçları vardır. Dağlarda yaşayan insanlar özgürlügüne daha düşkündür. Ayrıca toplumsal kurallara uyum sağlamakta güçlük çekerler (Ülger 2004: 63). Bunun yanında dağların kültürel anlamda da etkileri olmaktadır. Burke, Akdeniz ülkeleri üzerinden, dağların sosyal ve kültürel engel oluşturarak kültürel muhafazakârlığa sebep olduğunu, genç nüfusu göçe zorladığını aktarmıştır (Burke 2002: 71). İspanya, Bulgaristan ve Meksika gibi örneklerde olduğu gibi dağlar, nüfuz etmeyi ve siyasi birlik kurmayı zorlaştırıp, ülkenin bütüncül olarak ekonomik ve siyasi gelişmesini zorlaştırabilmektedir (Roskin 2009: 199). Bu şartlar söz konusu ülkelerde organizasyon bakımından merkeziyetçi değil âdemi merkeziyetçi eğilimlerin görülmesine neden olmuştur.

Dağlarda yaşayanların toplumsal düzene uyum sağlayamadıklarını belirtmiştik. Dağlar yoksul, sorunlu toplum sistemlerine, ovalar ise zengin, uyumlu toplum sistemlerine kaynaklık etmektedir (Kızılçelik 2006: 151). Dağların yani, bu izole bölgelerin benzer politik, milli ve kültürel grupları olmaktadır (Sorokin 1994: 147). Buralarda milliyetçilik duygusu son derece yüksek, ülke de doğal sınırlara ulaştığı için halkı da bu anlamda son derece enerjik olmaktadır (Göney 1979: 118). Bu durum Balkanlar'da ve Kafkaslar'da görülmektedir. Dağlar, her vadi veya platoyu bir şekilde izole etmiş, en azından buralarda yaşayanların bağlantılarını zayıflatmıştır. Bu nedenle çeşitli gruplar kendi sosyal, 
siyasi ve dini karakteristiğini koruyabilmiştir (Spykman 2013: 8) ve bunun sonucunda küçük siyasi yapıların oluşması kaçınılmaz olmuştur.

Dağların olduğu gibi düz arazilerin de siyasete dair sonuçları olmuştur. Diğer coğrafi ve beşeri unsurlara bağlı olarak düz araziler bazen imkân bazen engel teşkil etmiştir. Geniş ovalar, eğer iklim buna müsaitse, ziraat ve ulaşım olanağı sağlayıp farklı 1rk, dil ve kültürleri kaynaştırarak, istenmesi halinde insanlar ve toplumlar arasında iş birliği ve politik birlik oluşturmayı kolaylaştırabilmektedir. Geniş düzlükler, tarihte önemli rol oynamıştır. Suyun bulunduğu ve tarıma da elverişli alanlar hep göçebelerin ilgisini çekmiş, büyük göç ve istilaların hedef noktası olmuştur. Asya ve Avrupa'da benzer geniş düzlükler mevcuttur. Ancak Asya'da, Avrupa'daki gibi kuzeyden gelen soğuk havay1 yumuşatan dağ sıraları mevcut değildir (Montesquieu 1963: 489). Bu elverişli ortam Avrupa'nın kuzeyindeki geniş ovalarda, köyden şehre kadar irili ufaklı birçok yerleşimin kurulmasına sebep olmuş, bu durum eğer bataklık veya orman yok ise bölgeyi Avrupa'nın orta ve güneyine göre istilalara daha açık hale getirmiştir (Duverger 1984: 52). Steplerden gelen kavimlerin yaşam tarzlarından kaynaklanan hareketli ve enerjik karakteri bu bölgeye de yansımış, bölgenin; yüzyıllarca hareketli ve istikrarsız olmasına, kurulan devletlerin genel itibariyle kısa ömürlü olmasına, değişimlere uğramasına sebep olarak siyasete dair önemli bir birikim alanı olmasına neden olmuştur.

Arazilerde yalnızca dağlar, engel veya imkân sağlayan yer şekli değildir. Bu anlamda önemli etkilere neden olan bir diğer coğrafi unsur, akarsulardır. Bu alanlarda tarihin en eski dönemlerinden itibaren, pek çok yerleşim ve devlet kurulmuştur. Bu durumun ortaya çıkmasında su kaynaklarının etrafındaki araziyi verimli hale getirerek temel ihtiyaçların sağlanmasına olanak vermesi önemlidir. Örneğin; Mezopotamya medeniyeti Dicle ve Fırat nehirlerinin etrafında kurulmuşken, Mısır medeniyeti Nil nehri etrafında şekillenmiştir. Bu medeniyetlerin ortaya çıkışlarında iklim ve yer şekilleri gibi faktörler de göz ardı edilmemelidir. Ancak o dönemlerde yaşayan önemli toplulukların genelinin aynı coğrafyada yaşaması nedeniyle tarihçiler tarafından ön planda hep bu akarsular tutulmuştur.

Akarsular ulaşım olanağı sağlayarak karadan erişimi zor olan iç kesimlere nüfuz etme imkânı sağlamaktadır. Örneğin Kongo nehri yardımıyla Afrika'nın iç kesimlerine ilmi, siyasi ve ekonomik faaliyetler götürülmüştür. Bu nedenle nehir oradaki kolonileşmenin merkezi olmuştur (Göney 1979: 158). Bitki örtüsü karadan keşfi zorlaştırdığg için Amazon nehri de bölgenin keşfinde ana rotay1 oluşturmuştur. Nehirler ulaşım ve ekonomik faaliyet imkânı ölçüsünde etrafinda nüfusları toplamış, siyasi organizasyon ve yapılanmaların merkezi olmuştur. Mısır'da bölge, çöllerle kaplı olmasından dolayı temaslar önemli ölçüde Nil üzerinden sağlanmıştır. Nehrin haberleşmeyi kolaylaştırması politik örgütlenmenin tüm havzaya yayılmasını sağlamış ve böylece çok ileri istikrarlı bir toplumsal örgütlenme biçimi ortaya çıkmıştır (Duverger 1982: 82). Nil nehrinin siyaset bilimi açısından neden olduğu gelişmeler bununla sınırlı değildir. Çölün olumsuzluklarına karşın Nil çevresinde, taşmaların getirdiği çamur, sürekli olarak bir gübreleme sağlamış, bu sayede etrafinda oldukça verimli bir vadi 
oluşturmuştur. Bu taşmaların düzenli karakteri, Nil'den faydalanmayı kolaylaştırmış, insanlara suyunu kanallar vasıtasıyla biriktirecek bir sistem kurma imkânı sunmuştur. Ancak taşmaların düzensiz olduğu dönemlerde suya olan ihtiyaç zorba eğilimleri ortaya çıkarmıştır. Böyle bir durum, sulama sistemin kurulumunu, bakımını ve merkezileşmiş bir toplumsal örgütlenmeyi gerekli kılmıştır. Böylece sınıflı bir toplumsal yapının ortaya çıkmasında da Nil'in etkisi olmuştur. Fırat ve Dicle nehirleri de benzer imkânları sunmuştur. Ancak bölgenin dağlık yapısı daha baskın gelerek aynı merkezileşmeyi doğurmamış ancak düzensiz taşkınlar iktidarın merkezileşmesine neden olmuştur (Sorokin 1994: 150).

Akarsular konusunda siyasetle ilgili farklı çıkarımlar yapılabilir. Çünkü akarsuyun söz konusu etkilerinde debisi, sistemi ve akış yönü belirleyicidir. Nehrin ulaşıma elverişli olmaması farklı sonuçlar doğurabilmektedir. İçeriden dişa doğru akan bir nehir sistemi çevre ülkelerle birleşme eğilimlerine sebep olabilmektedir. Yine nehrin parçalı bir sisteminin oluşu, farklı vadiler oluşturmakta adem-i merkeziyetçi yapıları doğurmaktadır. Göllere benzer fonksiyonlar yüklenebilir. Ancak bataklıklar tartışmasız şekilde ayırıcı unsurlardır. Orta Avrupa, Sibirya örnekleri bunu göstermektedir (Spykman 2013: 9). Avrupa'da birbiriyle kesişmeyen birçok akarsu olması birçok ulusun da oluşmasına zemin hazırlamıştır. Buna rağmen akarsuların özellikle ilk siyasi örgütlenmelerdeki birleştirici rolü göz ardı edilmemelidir. Akarsuların rolü bu anlamda tartışmalıdır. Rejim ve debisine göre bazen birleştirici bir unsur bazen doğal bir sınır unsuru olarak engel halini almaktadır. Ama barış zamanlarında birleştiricilikteki rolü tartışılmazdır. Buradan anlaşılıyor ki bunu belirleyen insan faktörüdür. Akarsular, etrafında uygarlık dolayısıyla devletler doğurmuştur. Ekonomik ve siyasal hayatı şekillendirmiştir (Roskin 2009: 106). Bu durumda denize atfedilen siyasi, ekonomik ve toplumsal önemler akarsular için de geçerli olmaktadır.

\subsection{Kıyı Sahibi OIma - Karalarla Çevrili Olma}

Denizler ve okyanuslar, karalara göre yeryüzünde çok daha geniş bir alanı kaplamaktadır ve karalara göre çok farklı avantaj ve dezavantajlar sağlamaktadır. Ulaşım olanaklarının gelişmesiyle başka coğrafyalardaki ihtiyaçlara ulaşmak kolaylaşmış, denizlerin ekonomik yönden önemi daha da artmıştır. Bu gelişmeler farklı kültürlerden insanları daha fazla etkileşim içine sokmuştur. Bu etkileşim jeopolitik ve siyasi coğrafyanın ötesinde sonuçlar doğurmuştur. Antik Yunan uygarlığı, dağların tarıma ve iç kesimlere ulaşımı engellemesine karşın denize yönelmiştir. Denizlere açılarak maddi ve manevi ihtiyaçlarını karşılayabilmiş ve uygarlıklarını geliştirmiştir (Duverger 1984: 54). Bu durumun yansımaları politik alanda da olmuştur. Birbirlerine çok yakın olmalarına rağmen deniz kıyısındaki Atina'da demokrasi, iç kesimlerdeki Sparta'da ise aristokrasi benimsenmiştir (Spykman 2013: 7). Denizlerin sağladığı bu imkânlar siyasete dair yeni yaklaşımların ortaya çıkmasına ve yayılmasına imkân sağlamıştır. Çünkü soğuk iklim bölgeleri dışında deniz kıyıları, çeşitliliğin ve canlılığın olduğu, ekonomik ve toplumsal hayata sebep olmaktadır. Söz konusu bölgelerde deniz, insanları ve toplumları etkileşime daha açık hale getirirken, iç kesimlerde yaşamak tıpkı dağlar konusunda değinildiği gibi 
nispeten monotonluğa ve içe kapanıklığa neden olabilmektedir. Bu nedenle kıyılarda, gerek düşünsel olarak gerek siyasete dair faaliyetler daha çeşitli ve dinamiktir.

Denizlerin sağladığı dinamizm, ülkelerin yayılmalarını ve imparatorluklara dönüşmelerini kolaylaştırır. Tarihte küçük toprak parçasına sahip olduğu halde denizlerden faydalanmayı bilmesiyle siyasi olarak güç ve önem kazanan birçok devlet vardır. Jeopolitikle birlikte siyaset bilimi açısından bu avantaj en net şekilde ada devletlerinde görülmektedir. Tamamen sularla çevrili olan adalar, iklimin elverişli olduğu yerlerde emniyet açısından devamlı ve etkili olarak ekonomik ve siyasi organizasyonların kurulmasına uygun kara parçalarıdır (Göney 1979: 120).

İngiltere'nin Kıta Avrupa'sına karşı denizlere egemen olma yönünden üstünlüğünü coğrafi durumunun doğal bir sonucu olduğu ve bu durumun İngiltere'nin siyasetteki rolü ve gelişimiyle ilişkili olduğu düşünülebilir. Anakarayla bağlantısı olmayan suların doğal bir savunma hattı kurduğu Britanya Adası'nı işgal etmek çok zordur. Bu ada üzerindeki son başarılı işgal, Normanlar tarafindan 1066'da gerçekleşmiştir (Roskin 2009: 24). Böylece Kita Avrupa'sına göre siyasete dair farklı gelişmeler yaşanmış, yabancı müdahalesi olmadan siyasi kurumların kurulup geliştirilmesi mümkün olmuştur. Ayrıca bu coğrafi avantaj İngiltere'nin zoraki olarak büyük bir orduyu beslemeye gereksinim duymamasını beraberinde getirmiş, özellikle 17. yy’ da İngiliz krallarının parlamento ve derebeyleri üzerinde hâkimiyet kurabilecek sayıda askeri güce sahip olmamasına neden olmuştur. Böylece parlamenter demokrasi için bir zemin oluşmuştur (Kışlalı 1987: 32).

Britanya’nın denizden kaynaklanan doğal sınırları olmasına karşın, bu imkânın Almanya, Fransa gibi pek çok ülkede kısmen olması veya hiç olmaması coğrafi şartlara bağlı olarak Kıta Avrupa'sında rekabet içinde, çalkantılı bir siyasi tarihin yaşanmasına neden olmuştur. Aynı iklim kuşağı içerisinde bile kıyı kesimlerle iç kesimler büyük farklılık göstermektedir. İç kesimlerde coğrafi faktörler çeşitlenir; ormanlar, bozkırlar, yüksek ve alçak kesimler bir arada görülmektedir. Bu durum, farklı coğrafi unsurlar nedeniyle farklı şekillerde biçimlenmiş, örgütlenmiş, yerleşmiş toplulukların yaşaması, siyasete dair farklı talep ve gelişmelerin olması ve bu nedenle zaman zaman gerilimler yaşanması anlamına gelmektedir. Örneğin; Fransa, siyasal evrimini çok sert bir şekilde gerçekleştiren bir ülkedir. Coğrafya Fransa'nın sürekli güçlü bir ordu bulundurmasını zorunlu kılmış, kral istediğinde bu orduyu kullanarak meclisi dağıtabilmiştir (Kışlalı 1987: 32). Yine, Almanya'nın kuzeyde Baltık denizi, güneyde Alpler dışında bir doğal sınırının olmayıp Avrupa'nın ortaya yerinde düz bir ovada konumlanışı askeri bakımdan zayıfken parçalı bir siyasi yapıda olmasına, güçlü olduğunda ise yayılmacı bir politika izlemesine neden olmuştur (Roskin 2009: 195).

Denizlerin devlet açısından önemi büyüktür. Kıyı sahibi olmak her şeyden önce dış dünya ile serbest bir şekilde ilişkide bulunmak için şarttır. Bu durum devletin bağımsızlığını ve gücünü etkilemektedir (Göney 1979: 141). Bir deniz kıyısına sahip olmak başka ülkelerin topraklarından geçmeyi gerektirmediğinden öncelikle önemli bir ekonomik avantaj sağlar. Doğal limanlar ticareti 
kolaylaştırır, tarım ve sanayi buralarda yoğunlaşır, refah sağlar (Roskin 2009: 27). Bu nedenle ekonomik anlamda en verimli bölgeler denize açık olan alanlar olmuştur. Malların ve hatta fikirlerin dolaşımı bu nedenle kara yerine deniz üzerinden gerçekleşmiştir (Spykman 2013: 7). Bu durum tarih boyunca geçerli olmuştur. Tarihin başından itibaren, medeniyet geniş su havzaları etrafında gelişme göstermiştir. Antik Yunan medeniyeti Ege Denizi'nin çevresindeydi, Roma uygarllğı Akdeniz etrafındaydı. Daha sonra ise Akdeniz önemini yitirmiş, günümüzün Batı uygarlığı Atlantik Okyanusu'nu kuşatmıştır (Spykman 2013: 16). Denizler ve okyanuslar tarihin önemli bir bölümünde ekonomik ve kültürel etkileşimin, siyasete dair önemli gelişmelerin kaynakları olmuştur.

\section{Sonuç}

Tarih, yalnızca insanların birbiri ile olan mücadelesinden ibaret değildir. İnsanlık doğa ile de mücadele etmiştir. İnsanlığın tüm birikimi de bu mücadelelerin sonucudur. Siyaset de bu birikimler sonucunda ortaya çıkmış ve şekil almıştır. Coğrafya, insanoğlunu bazen bir arada yaşamaya itmiş bazen izole bir yaşam sürmesine neden olmuştur. Bu örnek, toplumsal anlamda da geçerlidir. Tüm bunlar zamanla alışkanlıklar, gelenekler halini almış, yeryüzünün farklı kesimlerinde yaşayan toplumların birbirinden farklılaşmasını sağlamıştır. Kendi dönemini ve kendinden önceki dönemleri inceleyen düşünürler de bu bilinç içerisinde görüşlerini ortaya koymuştur. Antik Yunan'dan itibaren birey ve toplumun; siyasete dair tutum, davranış ve eğilimleri, kurumların yapıları çevre faktörü dikkate alınarak yapılmıştır. Şüphesiz beş yüz yıl öncesine kadar coğrafya insan üzerinde çok baskın bir etkendi ve bir noktadan sonra aşılmaz olarak görülüyordu. Bu süreçte elbette teknoloji faktörünü de dikkate almak gerekir. Ulaşım ve bilgiye erişim imkânlarının kısıtlılığı coğrafya üzerinden siyaset bilimine dair bulgular elde etmek isteyen düşünürlerin fikirlerini de belirlemiştir. Yaşadığ 1 dönem şartları itibariyle çok geniş coğrafyaları gezme şansı yakalamış, çağdaşlarının çevre coğrafyalar hakkında eserlerini okumuş olsalar da, önemli bir bölümü yeni dünyaya dair fikirlerin dahi olmadığ dönemlerde yaşamışlar, gözlemler sonucunda günümüz tıp imkânlarıyla bile tespiti zor çıkarımlarda bulunmuşlardır. Tüm bunlar düşünürlere karşı pozitif bir alg1 oluştursa da unutmamamız gereken noktalar da vardır. Makalenin başında değindiğimiz Aristoteles de, İbni Haldun da, Montesquieu de kendi coğrafyalarını merkeze almış ve istisnai halleri hep bu coğrafyaların lehine kullanmışlardır. Bu durum düşüncelerinin evrensel olma durumuna ciddi engeller oluşturmaktadır. Tekniğin gelişmesiyle bu üç ismin başını çektiği görüşlerin önemli bir bölümünün yanlışlığı, aşırılığı ortaya konmuştur. Ancak bunu yaparken de benzer yanlışlıklar ve aşırılıklar yapılmıştır. Aydınlanma Çağı ile başlayan insan merkezcilik her alana yansımış, insan faktörünün toplum ve siyasete ilişkin konularda salt belirleyici faktör olarak algılanmasına neden olmuştur. Bunun yanında coğrafi keşiflerle birlikte coğrafya adeta bir araç haline dönüşmüştür. $O$ dönemlerde yaşamış düşünürlerin önemli bir bölümünün fikirleri sonucu süreç, siyasetin güç ilişkilerinin yaşandığı bir alan olarak görülmesiyle jeopolitik biliminin ortaya çıkmasıyla sonuçlanmıştır. Daha sonra jeopolitiğin siyasi üstünlüğü ve 
sömürgeciliği meşrulaştırma amacıyla determinist bir hal alması coğrafya-siyaset ilişkisini dar bir çerçeveye sıkıştırmıştır ve konuya ilgiyi azaltmıştır.

Günümüzden geçmişe doğru baktığımızda birey ve toplumla ilgili siyasete dair meseleler genellikle insan ve buna bağlı teknoloji ve gelişmişlik odaklı ele alınmış, farklılıklar ve hatta üstünlükler, güç kavramının türevleri olarak kullanılmıştır. Ancak günümüzde iletişim ve ulaşım imkânlarının bu denli gelişmesine karşın yeryüzünün farklı kesimlerinde yaşayan insanlar arasında, yalnızca güç ilişkilerine değil, devlet kavramına, örgütlenme biçimlerine, özgürlük eğilimlerine, siyasete dair tutum ve davranışlara dair pek çok yönden farklılıkların oluşu, teknoloji ne kadar ilerlemiş olsa da coğrafya-siyaset arasındaki ilişkinin yalnızca insan odaklı olmadığının göstergesi olmuştur. Söz konusu etkiler kültürlerde, gelenek ve göreneklerde dolaylı da olsa görülebilmektedir. $\mathrm{Bu}$ nedenle insana dair bir mesele olan siyaset açısından da coğrafya son derece önemli bir etkendir. $\mathrm{Bu}$ etkeni, siyaset biliminin sorunlarını ele alırken ne Aydınlanma çağı öncesi düşünürler gibi determinist olarak ele almalı ne de Jeopolitikçiler gibi salt güç odaklı ele almalıyız. Çünkü coğrafya çok boyutludur. Aynı zamanda bir birikim alanıdır. Coğrafyanın insanı, insanın coğrafyayı etkilediğinden daha çok ve daha uzun süre etkilediği bir gerçektir. Teknik imkânların gelişmesi, coğrafyadan kaynaklanan olumsuzlukları bir nebze azaltsa da tarih boyunca bu olumsuzluklar, toplumlar arasında gelişmişlik yönünden kapatılması zor makasların açılmasına neden olmuştur. Teknik ve ulaşım imkânlarının gelişmesiyle birlikte toplumlar arasında doğal kaynaklar yönünden mevcut farklar açıkça ortaya çıkmıştır ve günümüz siyaset bilimi bu farklar etrafında şekillenmektedir. Coğrafyanın ortaya çıkışında etkili olduğu toplumsal ve siyasete dair süreçler hâlen yine coğrafya tarafından şekillenmektedir. Bu bakış açısı, determinist veya coğrafyayı kutsayan bir yaklaşım olarak görülmemelidir. Siyaset bilimi, beşeri ve fiziki faktörleri dengeli bir şekilde ele alabilecek derinliğe sahiptir. Çünkü nası1 ki her coğrafi unsur aynı etkiyi gösteremeyip bir başka coğrafi unsur etkisi daha baskın gelebiliyorsa insan ve toplumu dolayısıyla siyaseti etkileyen unsurlar arasında bazen coğrafya da, siyaset bilimi açısından önemli diğer faktörler tarafından baskılanabilmektedir.

Makale 1şığında, coğrafi unsurların neden olduğu coğrafi farklılıkların; toplumların yaşayış, beşerî ilişkileri, siyasal tutum ve davranışları gibi siyaseti ilgilendiren pek çok konuda etkili olduğunu söylemek mümkündür. Görülmektedir ki, coğrafya, siyasete dair birikimi, düşünceleri ve faaliyetleri tümüyle belirlemese de gözden etkilemektedir. Zira, makalede yer alan örnekler ve değerlendirmeler göstermiştir ki, siyasete dair tartışmalarda coğrafya için, belirleyici değil etkileyici bir faktör ifadesini kullanmak doğru bir bulgu olacaktır. Bu nedenle makale sonucunda, insan faktörü ve coğrafya faktörünün birlikte ve bir denge içerisinde ele alınması halinde, siyaset bilimine farklı bir bakış açısı getirmenin mümkün olacağı sonucuna varılmıştır. 


\section{Kaynakça}

Arı, Tayyar (1999) Uluslararası İlişkiler, Alfa Basım Yayım Dağıtım, İstanbul.

Braudel, Fernand (1996) Uygarlıkların Grameri. (Çev. Mehmet Ali Kılıçbay). İmge Yayınları, İstanbul.

Burke, Peter (2002) Fransız Tarih Devrimi: Annales Okulu. (Çev. Mehmet Küçük). Doğu Batı Yayınları, İstanbul.

Demir, Ali Faik (1998) “Jeopolitiğe Günümüzden Bir Bakış”, Uluslararası Politikada Yeni Alanlar Yeni Bakışlar, (Der. Faruk Sönmezoğlu). Der Yayınları, İstanbul.

Demirci, Ali (2011) "Küreselleşen Dünyamızda Coğrafyanın Siyasal Gücü Ve Türkiye Ölçeğindeki Rolü”. Marmara Coğrafya Dergisi, C. 12, ss. 1-16.

Dönmezer, Sulhi (1984) Sosyoloji. (9. Baskı). Savaş Yayınları, Ankara.

Duverger, Maurice (1973) Metodoloji Açısından Sosyal Bilimlere Giriş, (Çev. Ünsal Oskay). Bilgi Yayınevi, Ankara.

Duverger, Maurice (1982) Siyaset Sosyolojisi. (2. Baskı). (Çev. Şirin Tekeli). Varlık Yayınları, İstanbul.

Duverger, Maurice (1984) Politikaya Giriş. (2. Baskı). (Çev. Samih Tiryakioğlu). Varlık Yayınları, İstanbul.

Eğribel, Ertan (2006) "XIX. Yüzyıl Batı Yayılmacıllı̆ı ve Jeopolitik Eksenler: Batı İçi Ayrımlar ve Hayat Sahası Çekişmesi”, Ertan Eğribel- Ufuk Özcan (Ed.). Sosyoloji Yıllı̆̆g-Kitap 15: Sosyoloji ve Coğrafya. Kızılelma Yayıncilık, İstanbul. ss. 207-220.

Findıkoğlu, Ziyaeddin Fahri (1940) "İbn Haldun: Coğrafya Telakkisi”, İş Ü̧̧ Aylık Ahlâk ve İçtimaiyat Mecmuasi, C. VI ss. 49-59.

Göney, Süha (1979) Siyasi Coğrafya. C. II, İstanbul Üniversitesi Edebiyat Fakültesi Yayınları, İstanbul.

Göze, Ayferi (1959) Devletin Ülke Unsuru: Sinırlarl Ve Devletle Olan Münasebeti. İstanbul Üniversitesi Hukuk Fakültesi, İstanbul.

Günel, Kamil (2006) "Alman Coğrafya Ekolü”, Ertan Eğribel- Ufuk Özcan (Ed.). Sosyoloji Yllll̆ğı-Kitap 15: Sosyoloji ve Coğrafya. Kızılelma Yayıncılık, İstanbul. ss. 189-211.

Hacısalihoğlu, Yaşar (2008) "Kuramsal ve Kavramsal Bir Çözümleme: Mekân- Güç - Çatışma ve Jeopolitik". Stratejik Araştırmalar Dergisi, C.1. ss. 22-44.

İbni Haldun (1982) Mukaddime. C. I, (Haz. Süleyman Uludağ). Dergâh Yayınları, İstanbul.

Kışlalı, Ahmet Taner (1987) Siyaset Bilimi. Ankara Üniversitesi Basın Yayın Yüksek Okulu Yayınları, Ankara.

Kışlalı, Ahmet Taner (2004) Siyaset Bilimi. (Ed. Nüvit Gerek). Anadolu Üniversitesi, Eskişehir.

Kıvılcımlı, Hikmet (1974) Tarih Tezi. (2. Baskı). Tarih Ve Devrim Yayınları, İstanbul.

Kızılçelik, Sezgin (2006) "Sosyolojide Coğrafyacı Görüşler: İbni Haldun, Montesquieu Ve Fernand Braudel Ekseninde Bir Değerlendirme”. Ertan Eğribel- Ufuk Özcan (Ed.). Sosyoloji Ylllı̆̆l-Kitap 15: Sosyoloji Ve Coğrafya Kızılelma Yayıncılık, İstanbul. ss. 138-155.

Kösemihal, Nurettin Şazi (1982) Sosyoloji Tarihi. Remzi Kitabevi, İstanbul.

Memiş, Ekrem (1990) Tarihi Coğrafyaya Giriş. Selçuk Üniversitesi Eğitim Fakültesi Yayınları, Konya.

Montesquieu (1963) Kanunların Ruhu Üzerine. C. I, (Çev. Fehmi Baldaş). MEB Yayınları, İstanbul.

Morgenthau, Hans (1970) Uluslararası Politika. (Çev. Baskın Oran - Ünsal Oskay). Türk Siyasi İlimler Derneği, Ankara.

Oktay, Cemil (2003) Siyaset Bilimi İncelemeleri. Alfa Yayınları, İstanbul.

Özcan, Ufuk (2006) "Coğrafya/Mekân Üzerindeki Beşerî Etkinlik Açısından Batı Ortaçağı Ve Feodalizm-Bizans İkiliği”. Ertan Eğribel- Ufuk Özcan (Ed.). Sosyoloji ylllı̆̆l-Kitap 15: Sosyoloji ve coğrafya. Kızılelma Yayınc1lik, İstanbul. ss. 336-359.

Roskin, Michael (2009) Çağdaş Devlet Sistemleri: Siyaset, Coğrafya, Kültür. (Çev. Bahaeddin Seçilmişoğlu). Adres Yayınları, Ankara.

Say, Seyfi (2011) İbn Haldun'un Düşünce Sistemi Ve Uluslararası İlişkiler Kuramı. İlk Harf Yayınevi, İstanbul. 
Sorokin, Pitirim (1994) Çağdaş Sosyoloji Kuramları. (Çev. M. M. Raşit Öymen). Kültür Bakanlığı Yayınları, Ankara.

Sönmezoğlu, Faruk (1989) Uluslararası Politika ve Dış Politika Analizi, Filiz Kitapevi, İstanbul.

Spykman, Nicholas (2013) "Dış Politika Ve Coğrafya I-II". (Çev. Aşkın İnci Sökmen). Esra Diri (Ed.) Uluslararası İlişkilerde Anahtar Metinler. Uluslararası İlişkiler Kütüphanesi, İstanbul. ss. 3-43.

Strabon (2000) Geographika: Antik Anadolu Coğrafyası, (Çev. Adnan Pekman), Arkeoloji ve Sanat Yayınları İstanbul.

Ülger, İbrahim (2004) İbni Haldun- Işı̆̆ıı Kaynă̆ Doğu. Berfin Yayınları, İstanbul. 